\title{
USE OF RENEWABLE ENERGY IN AQUACULTURE: AN ENERGY AUDIT CASE-STUDY ANALYSIS
}

\author{
IOAKEIMIDIS C. \\ POLATIDIS H.* \\ HARALAMBOPOULOS D.
}

\author{
Energy Management Laboratory, Dept. of Environment \\ University of the Aegean \\ University Hill, Xenia Building, Mytilene 81100, Greece
}

Received: 25/09/12

Accepted: 09/04/13 *to whom all correspondence should be addressed: e-mail: hpolat@env.aegean.gr

\begin{abstract}
In this paper we propose a framework for energy audit and renewable energy utilization for a Mediterranean fish hatchery station. A concise literature review concerning the use of renewables in aquaculture is provided, followed by a step by step framework for energy audit in aquaculture stations. The developed framework is subsequently applied to a real case study concerning an aquaculture unit in Greece. A combined PV and Solar-Thermal panel project is proposed, based on the energy audit results. The well-known clean energy software RETScreen, developed by Natural Resources of Canada, has been utilized as an assessment tool of the proposed project. It was found that that the proposed project could not fully cover the electric and thermal load of the station; nevertheless, the project is economically viable and could de realized, provided that the necessary financial resources become available to the entrepreneurs.
\end{abstract}

KEYWORDS: Aquaculture, Energy Audit, Renewable Energy, RETScreen, Greece.

\section{INTRODUCTION}

It is widely acknowledged that fish supplies from world fisheries are unlikely to increase substantially and that the expansion of the aquaculture sector will probably provide the solution to the problem of the projected shortfalls (Chamberlain and Rosenthal, 1995). Although European Aquaculture makes up only a small percentage i.e. 3.9\% (FAO, 2006) of the worldwide aquaculture production, it presents considerable growth (Blancheton, 2000).

The aquaculture production of seabass and seabream in the Mediterranean basin has been one of the most highly developed seafood industries in Europe (Theodorou, 2002). Greece in particular, has become the leading country among the EU in the aquaculture sea cage farming of seabream and seabass (Belias et al., 2003). Its production share accounts for approximately $52 \%$ for the seabream and $46 \%$ for the seabass of European production. The success came up due to the ideal environmental conditions and the availability of well protected areas, suitable for cage farming installations (Papoutsoglou, 2000). Nowadays, the production of seabream and bass in Greece has already exceeded the 80,000 tones per year (CIHEAM, 2005).

One of the major problems that modern aquaculture is facing worldwide, is the increased production cost which is directly linked to the increased operational and maintenance cost of the hatchery stations (Colt et al., 2008). In the operational cost of a hatchery station, several estimates are included such as live feed, chemicals, power, fuel, maintenance, consumables, administration etc. A marine fish hatchery station is a very intensive production system and exhibits high energy demand. This is because of its complex structure, the critical environmental conditions needed for the rearing of the young fish larvae (e.g. specific water \& room temperature, salinity, dissolved oxygen, etc.), as well as the numerous sophisticated mechanical equipment i.e. advanced water pups, UV filters, air conditioning, heaters, and lighting required.

In this paper we propose a framework for energy audit in aquaculture, we apply it in a large scale fish hatchery station in Greece and we investigate the possibilities for renewables exploitation in 
order to cover part of the recorded energy demand. In the next section we provide a synoptic literature review on the use of renewables in aquaculture; subsequently we develop a step by step framework for energy audit in aquaculture and then we provide an application of the framework to a case-study hatchery station in Western Greece. Following, we investigate the possibilities for exploiting solar PV and Solar-Thermal energy in order to cover part of the electrical and thermal loads. The well-known clean energy software RETScreen@ International ${ }^{1}$, developed by Natural Resources Canada, has been utilized as an assessment tool for the proposed project. Finally, we summarize our conclusions.

\section{USE OF RENEWABLE ENERGY SOURCES IN AQUACULTURE}

The benefits from the use of Renewable Energy Sources (RES) can be of major importance with viable results, particularly when used in large scale aquaculture projects (Skoglund et al., 2010). The introduction and application of new energy technologies in the marine fish hatchery production is of major importance and in this aspect several studies have investigated the use of RES in off-shore aquaculture with encouraging results (Menicou and Vassiliou, 2010).

Colt et al. (2008), evaluated the resource and energy requirements of six different types of landbased hatchery production systems of Atlantic salmon smolts; in the same article the authors mention that up to 2008, there were less than 20 published studies concerning the energy requirements of aquaculture production systems.

Studies related to the assessment of alternative aquaculture technologies of salmonid species, in respect to minimize energy consumption, were done by Ayer and Tyedmers, 2009; Pelletier et al., 2009; and Pelletier and Tyedmers, 2008. A broader study, concerning the environmental impacts of aquaculture in regard to energy demand and consumption can be found by Ayer et al., 2007.

Pelletier and Tyedmers (2008), presented a detailed sustainability assessment dealing with the high energy flows in aquaculture and its products. Lai and Linb (2006), proposed a small-scale wind power system in a land prawn aqua farm in Taiwan, to fulfill its energy demand. Ayer et al. (2009), studied issues related to seafood production with an emphasis on cleaner and more efficient harvesting, culture, processing and distribution of seafood products, while they gave special attention to innovations related to cleaner practices and processes in regard to sustainable aquaculture products.

Generally, the energy and resource consumption of aquaculture production systems have not been clearly documented and compared with existing production systems (Colt et al., 2008). Thus, it seems that there is some lack of knowledge on the use of RES in fish hatchery stations.

In the next section we develop and propose the main steps of a framework for energy audit in aquaculture.

\section{DEVELOPMENT OF A FRAMEWORK FOR ENERGY AUDIT IN AQUACULTURE}

Energy audit is initially linked to the detailed recording of the energy flows (demands) of a studied system. In that aspect, it is proposed that the examiners must study and understand the corresponding system in full detail. A recent case-study analysis for a cement factory in Greece is presented by Moussiopoulos et al., 2012. Figure 1, presents a step by step framework for Integrated Energy Audit in Aquaculture units. The framework consists of four (4) steps: Step1: Identification of the different production methods, techniques and processes; Step2: Classification of the different type of energy usage per used equipment; Step3: Detailed recording of the energy demands; Step4: Use of an integrated energy technology assessment method in order to perform a technical, cost and feasibility analysis.

Steps 1 to 3 could be usually applied in a straightforward way, nevertheless, Step 4 includes the application of some kind of 'clean' energy technology evaluation model like, for example, the RETScreen (Economou, 2010; Modi et al., 2009; Harder and Gibson, 2001 ), and TRNsys (Choi et al., 2011).

\footnotetext{
${ }^{1}$ http://www.retscreen.net
} 


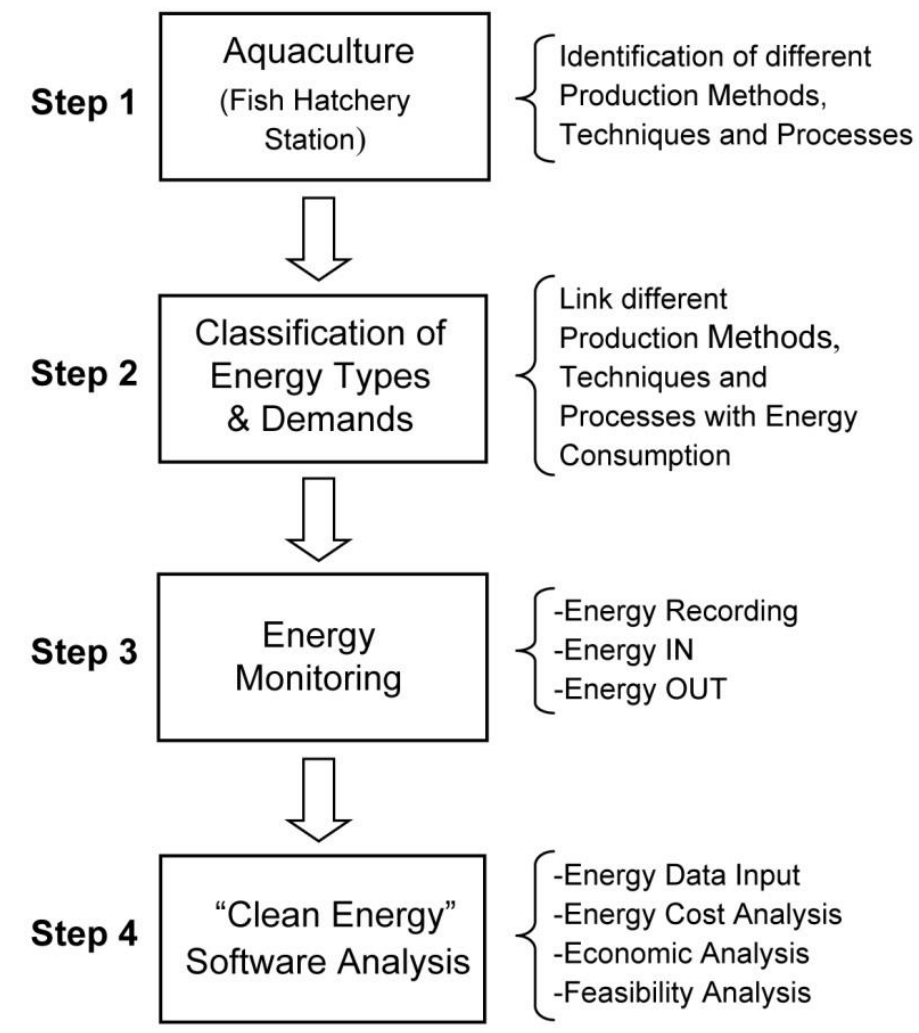

Figure 1. Proposed framework for energy audit in aquaculture; A step by step analysis

Particularly, the Clean Energy Project Analysis Software RETScreen seems to be a promising tool in order to evaluate an integrated energy production system (Rehman, 2005; Houri, 2006; Rehman et al., 2007). RETScreen, constitutes a unique decision-making support tool that seeks to implement renewables in many different applications from household to industry scale. It is capable of assessing energy resource availability at project site, equipment performance, initial project costs, "base case" \& "proposed case" scenarios, on-going and periodic project costs, avoided energy costs, financing, taxes on equipment and revenues, environmental characteristics of the displaced energy, environmental credits and/or subsidies (Mohandes et al., 2000). Its main prospects are to reduce the cost of pre-feasibility studies, disseminating knowledge, help entrepreneurs make better decisions and train them in regard to optimal analysis, technical and financial viability of possible RES projects.

In the next section we present an application of the proposed framework for energy audit in aquaculture in a fish hatchery station in Western Greece.

\section{IMPLEMENTATION OF THE PROPOSED FRAMEWORK FOR ENERGY AUDIT IN AQUACULTURE}

\section{Marine Fish Hatchery Station Description}

The studied hatchery station is situated in the Western Hellenic Coast, close to the city of Nafpaktos (Figure 2). More than 25\% of Greek fish farms are located in Western Greece (Dimitriou et al., 2007).

The annual production of the studied hatchery station exceeds the 35 million fish larvae per year. The produced fish species are seabream and seabass white seabream. Total production includes 8.0 million larvae of seabream, 25.5 million larvae of seabass and 1.5 million larvae of White Seabream. It should be noted that a typical medium scale fish farm, of total production 200 tones per year, needs approximately 1 million fish larvae (Moretti et al., 2005). 


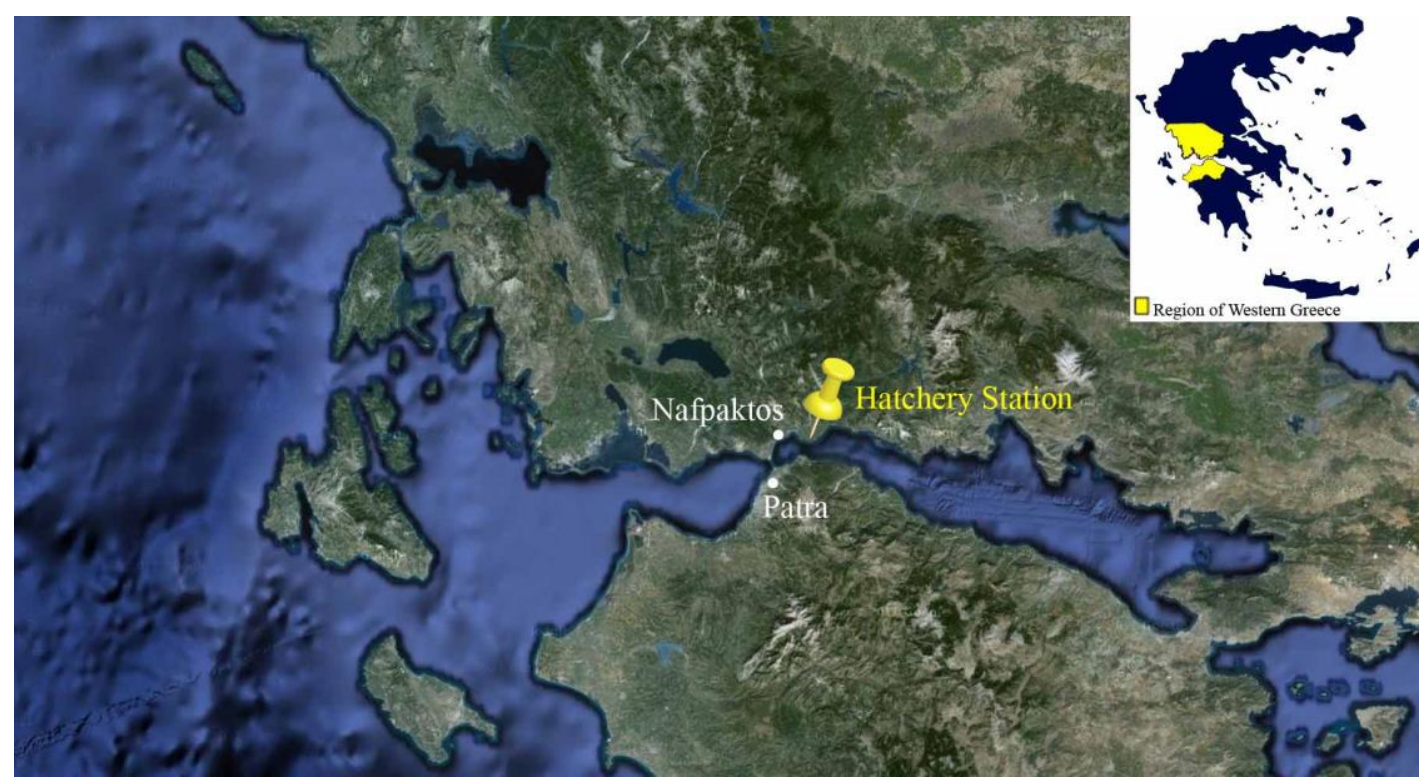

Figure 2. Location of the studied marine hatchery station (Western Greece)

The examined hatchery station follows the layout of a typical Mediterranean fish hatchery station. In particular, it is divided in the following five major units: i) Broodstock Unit; ii) Live Feed Unit; iii) Hatchery Unit; iv) Weaning Unit; v) Support Units. In the following Figure 3, we illustrate the production cycle and the type of energy demand of each unit of the Marine Fish Hatchery Station.

In the broodstock unit, the maintenance of adequate stocks of parent fish is taking place in order to assure timely supply of fertilized eggs. The fertilized eggs are subsequently transferred in the next production unit for the larval development. In the live feed unit, the large scale production of microalgae, rotifer and artemia is taking place. Fish larvae are fed exclusively on live feed. Following, the Hatchery Unit is the main part of the hatchery station. It is where the eggs are hatched and incubated and where the first feeding of the young fish larvae occurs. Usually, in this particular unit the energy demands are moderate high. In the Weaning unit, the young fish larvae are reared before they are moved into the sea cages.

The energy demands of the Broodstock unit are moderate high due to the water supply circuit, intense lighting, and controlled room and water temperature. In the Live Feed unit there exists a series of equipment used constantly in order to assure totally controlled rearing conditions, resulting in increased energy demand. In the Hatchery unit water temperature is the most important variable to be controlled, (between $18-19^{\circ} \mathrm{C}$ ), since the young fish larvae are very vulnerable in temperature fluctuations. According to the month-of the year, water might need heating or cooling. A boiler and a chiller are used for that purpose. In the Weaning unit the energy requirements are not that intense and mainly have to do with the water supply pumps. The energy demand is mainly associated with the controlled water temperature and quality parameters, the room temperature and lighting.

\section{Energy monitoring}

The monitoring of the energy demand of the particular aquaculture unit took place in situ, with successive visits in the hatchery station and detailed recording of the equipment used. For each part of the aquaculture station, data were collected and corresponding analytical databases were created. The resulted energy data are given in Table 1, while the detailed energy demands recorded can be found in Appendix 1, Table 6.

As it can be seen out from Table 1, the total installed capacity is approximately $2.1 \mathrm{MW}$. In order to cover locally the increased energy demands, a diesel oil power production substation has been installed in the site area by the Public Power Corporation.

During the yearly operation of the Hatchery Station, there is a three month period in which the Station operates in lower capacity. This is due to operational programming and maintenance reasons. Figure 4 presents the monthly energy demands $(\mathrm{kWh})$ of the Hatchery Station for two successive years i.e. 2010, 2011, while Figure 5 shows the monthly electric and thermal load share (average values for 2010 and 2011). 


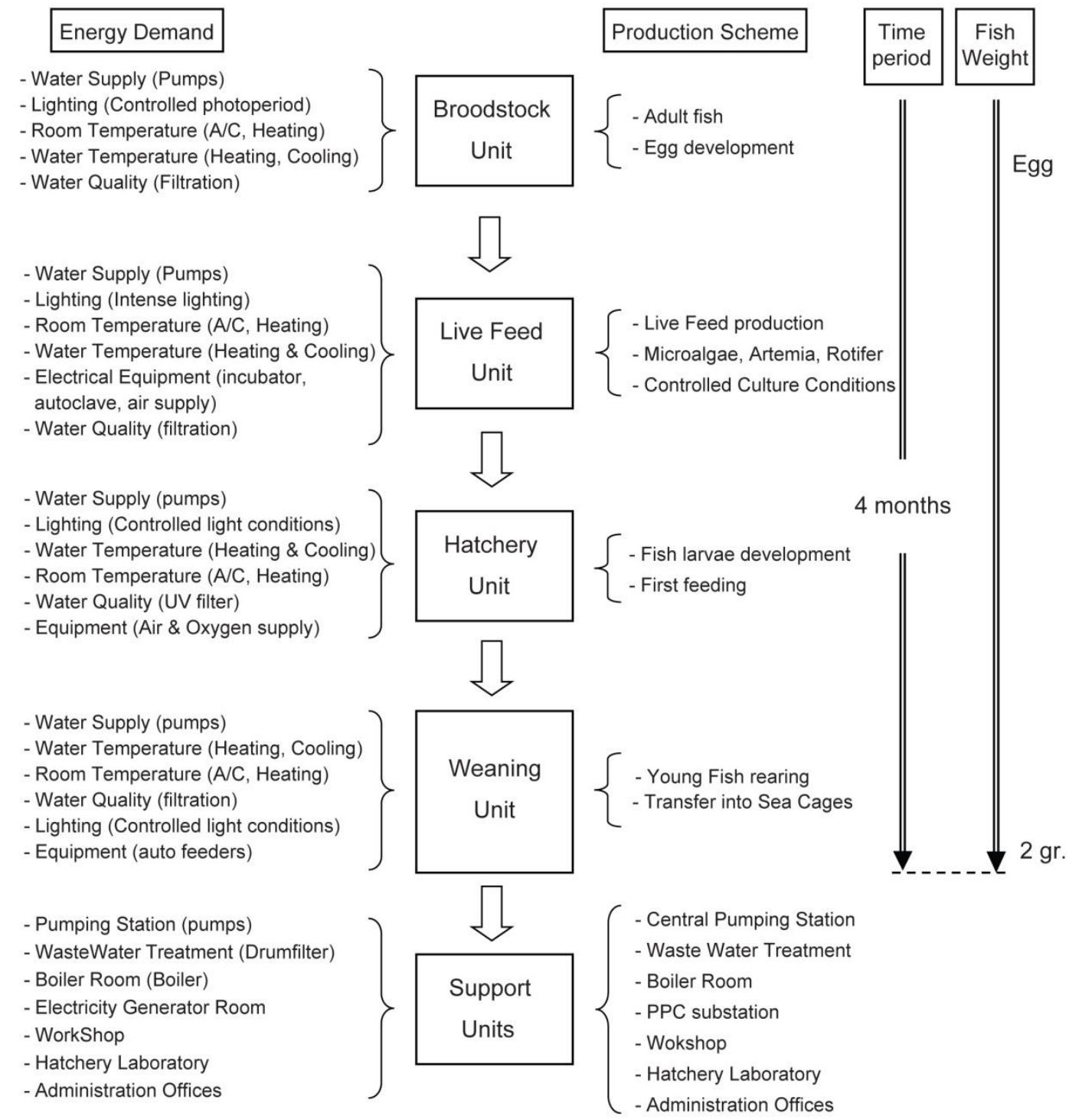

Figure 3. Production cycle and type of energy demand of each unit of the Marine Fish Hatchery Station

Table 1. Energy demand of the aquaculture unit

\begin{tabular}{lcrr} 
& $\begin{array}{c}\text { LOAD } \\
\text { TYPE }\end{array}$ & $\begin{array}{c}\text { TOTAL } \\
\mathrm{kW}\end{array}$ & $\begin{array}{r}\text { TOTAL } \\
\mathrm{kWh} / 24 \mathrm{~h}\end{array}$ \\
\hline A. LIVE FEED UNIT & Electricity & 168.05 & $1,622.82$ \\
\cline { 2 - 4 } & Thermal & 56.0 & 340.00 \\
\hline B. HATCHERY UNIT & Electricity & 152.13 & 1278.71 \\
\cline { 2 - 4 } & Thermal & 1048.00 & 3144.90 \\
\hline C. BROODSTOCK UNIT & Lighting & 1.45 & 8.7 \\
\hline D. WEANING UNIT & Electricity & 382.00 & 3849.00 \\
\hline E. DRUMFILTER & Electricity & 33.55 & 369.05 \\
\hline F. FATTENING SECTOR & Electricity & 44.00 & 308.00 \\
\hline G. CENTRAL PUMPING & Electricity & 189.00 & 2004.00 \\
STATION & Electricity & 17.20 & 94.90 \\
\hline H. ADMINISTRATION & & $2,091.38$ & 13019.18 \\
\hline BUILDING & & & \\
\hline \multicolumn{1}{c}{ TOTAL } &
\end{tabular}




\section{Monthly Energy Demands}

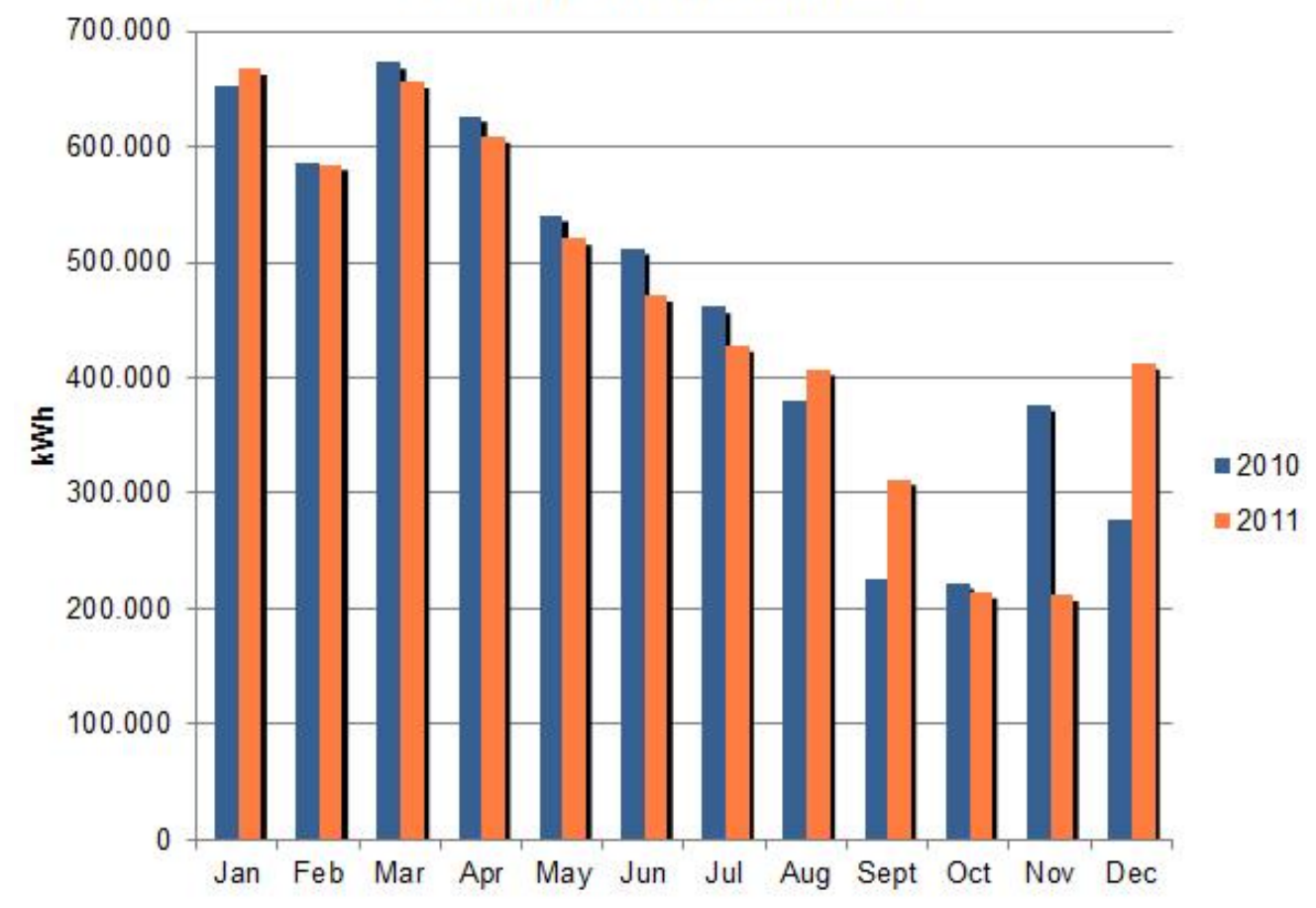

Figure 4. Monthly energy demands of the hatchery station for years 2010 and 2011

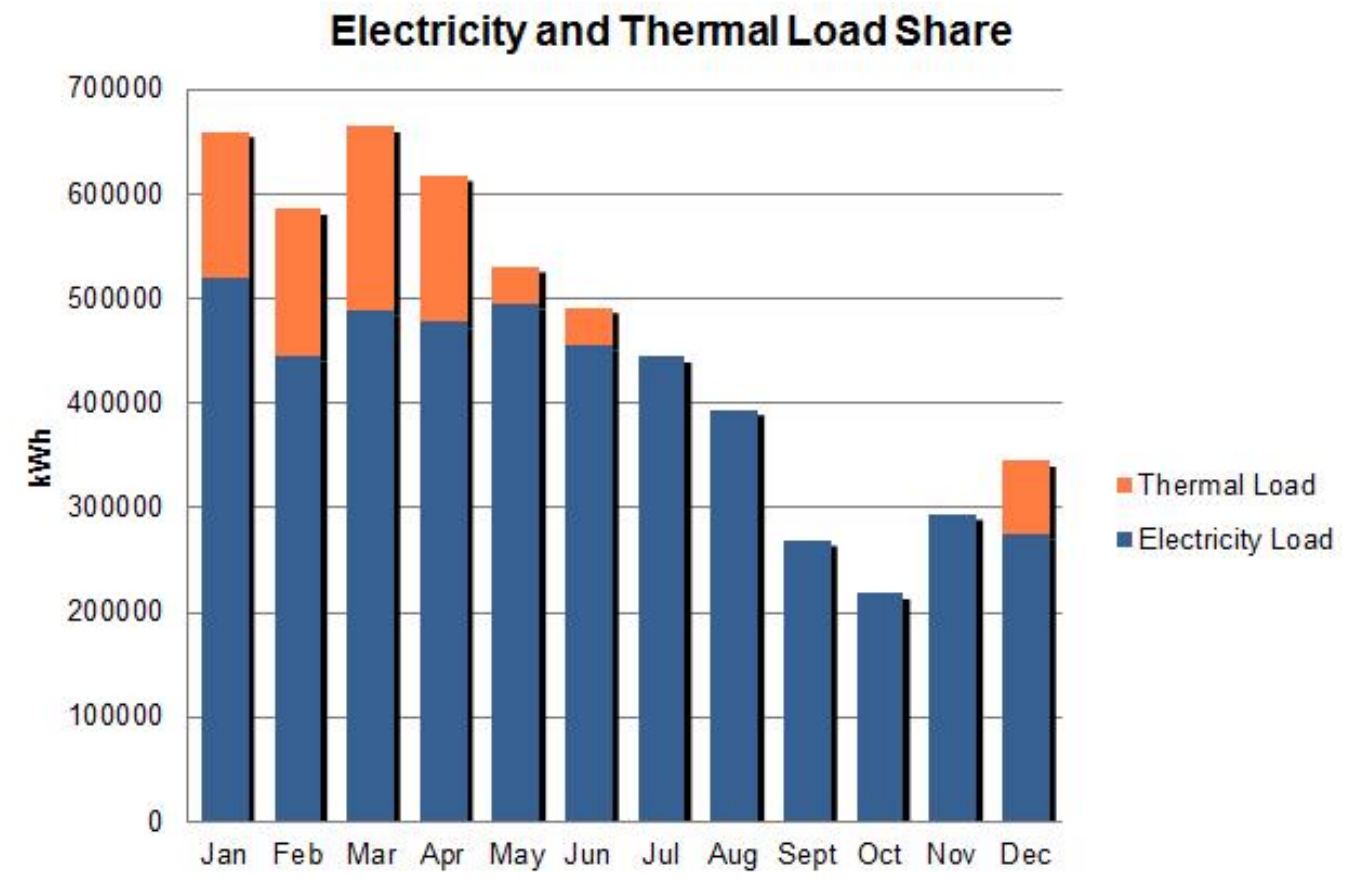

Figure 5. Share of electricity and thermal load of the hatchery station

In the next section we present an application of the 'clean' energy software RETScreen in order to assess the technical and financial viability of the introduction of RES to cover part of the energy demand of the particular aquaculture station. 


\section{CLEAN ENERGY RETScreen ANALYSIS}

\section{Introduction}

An integrated PV and Solar-thermal panel system designed to fulfill total energy demand (approximately 4,752,000 kWh of electricity and 737,733 kWh thermal on a yearly basis) couldn't be achieved because of not enough adequate land, where the installation could be developed. Moreover, because we are dealing with a large project of high initial investment cost we didn't want to add on that by buying extra land. Our approach is to identify the best possible set up, suited for the available space. In our case study, the available space for the RES system development is approximately $22,700 \mathrm{~m}^{2}$ of land space and $15,000 \mathrm{~m}^{2}$ of flat roof space; Land and roof space, are suitable for PV and Solar-Thermal panel installment.

After consulting with the engineers of the hatchery station it was decided to install $120.3 \mathrm{KW}$ of Solar-thermal panels (501 panels in $\left.2.800 \mathrm{~m}^{2}\right)$ and $1.5 \mathrm{MW}$ of PV panels $\left(6,250\right.$ panels in $\left.34,000 \mathrm{~m}^{2}\right)$. Total covered area would be $36,800 \mathrm{~m}^{2}$, corresponding in $97.6 \%$ coverage of the available space. So, the proposed project development will take almost full advantage of the available space, without adding extra costs in the initial investment. In the following Table 2, the technical characteristics of the proposed project are given.

Table 2. Technical characteristics of the proposed project

\begin{tabular}{lrrr}
\hline & & PV & Solar-Thermal \\
\hline Panels (240W) & No: & 6,250 & 501 \\
Capacity & $\mathrm{kW}:$ & 1500 & 120.3 \\
Surface area & $\mathrm{m}^{2}:$ & 34,000 & 2,800 \\
Total Surface area & $\mathrm{m}^{2}:$ & \multicolumn{2}{c}{36,800} \\
\hline
\end{tabular}

The RETScreen Clean Energy Project Analysis (V. 4.0) software has been chosen as an analysis tool. RETScreen is developed specifically in order to facilitate the identification and tabulation of all costs and perform an energy production and financial analysis. Next, technical and financial parameters are analyzed for our proposed project.

\section{Technical Analysis}

\section{PV Installation}

The electricity demand will be partially fulfilled by the PV panels. A total installation of $1.5 \mathrm{MW}$ is chosen, corresponding in 6,250 PV panels, each of 240W capacity. The PV panels that are selected for the installation are made of polycrystalline copper tubes with the following specifications: efficiency $11.34 \%$, capacity factor $17.5 \%$, dimensions $2.35 \times 1.07 \mathrm{~m}$, gross area $2.51 \mathrm{~m}^{2}$ per panel. For preventing shading effect and having adequate space for maintenance and operational purposes a total gross surface area of $34,000 \mathrm{~m}^{2}$ will be needed. It is calculated that the annual electricity produced could supply about $50 \%(2,607,633 \mathrm{kWh})$ of the electricity demand.

\section{Solar-Thermal Installation}

In order to partially fulfil the heating demand, solar-thermal panels of $240 \mathrm{~W}$ capacity each are chosen. The dimensions of each panel are $2.36 \times 1.07 \mathrm{~m}$ with a gross surface area of $2.53 \mathrm{~m}^{2}$ per panel. A number of 501 solar-thermal panels will be installed needing a total surface area of 2,800 $\mathrm{m}^{2}$, including on that the appropriate maintenance and operational space as well as prevention of shading effect. It is calculated that the annual thermal energy produced could fulfil almost $100 \%$ $(737,733)$ of the thermal demand.

\section{Economic Feasibility Analysis}

An economic feasibility study was performed for the proposed project. Primarily, we had to calculate the detailed initial cost (Table 3) for both PV and Solar-Thermal installations.

Apart from the initial cost, needed for the development of the proposed project, there are also additional costs i.e. "Operation \& Maintenance cost", on a yearly basis, for both projects, which have been taken into account for the economic feasibility analysis. The corresponding O\&M costs are $15,000.0 €$ and $10,000.0 €$ respectively for the PV and Solar-Thermal panel installations. 
Table 3. Detailed installation cost analysis for the proposed project

\begin{tabular}{lcr}
\hline & PV Inst. & $\begin{array}{c}\text { Solar-Thermal } \\
\text { Inst. }\end{array}$ \\
\hline Pre-Feasibility study & Cost $(€)$ & Cost $(€)$ \\
Panels & 40,000 & 30,000 \\
Panel bases & $2,718,750$ & 257,514 \\
Inverter & 331,250 & 50,601 \\
Panel installation & 397,500 & - \\
\hline TOTAL & 159,000 & 16,283 \\
\hline GRAND TOTAL & $3,646,500$ & 354,398 \\
\hline
\end{tabular}

The total investment for the proposed project is $4,000,898.0 €$, corresponding in $3,646,500.0 €$ for the PV installation and $354,398.0 €$ for the Solar-Thermal installation. Subsequently, a discount rate of $7 \%$ was used, in order to assess the financial feasibility of the given project. RETScreen software uses the discount rate in order to calculate the annual live cycle savings. Financial parameters are summarized in Table 4.

Table 4. Input financial parameters

\begin{tabular}{lccc}
\hline & & PV Inst. & Solar Inst. \\
\hline Inflation Rate & $:$ & $2.7 \%$ & $2.7 \%$ \\
\hline Project Life & $:$ & $25 \mathrm{yrs}$ & $20 \mathrm{yrs}$ \\
\hline Debt Ratio & $:$ & $70.0 \%$ & - \\
\hline Debt Interest Rate & $:$ & $6.0 \%$ & - \\
\hline Debt Term & $:$ & $20 \mathrm{yrs}$ & - \\
\hline Incentives and Grants & $:$ & $30.0 \%$ & $0.0 \%$ \\
\hline Discount rate & $:$ & $7.0 \%$ & $7.0 \%$ \\
\hline $\begin{array}{l}\text { Electr. Export Escal. } \\
\text { rate }\end{array}$ & $:$ & $5.2 \%$ & - \\
\hline Fuel Cost Escal. rate & $:$ & - & $2.5 \%$ \\
\hline
\end{tabular}

For the PV installation, we consider a 25 years project life. On the other hand, for the Solar-Thermal installation, since we are dealing with a smaller project, a 20 years project lifetime is considered, while no incentives were taken into consideration since there is currently no relevant economic aid on such investments. Table 5 presents a summary of the financial analysis performed.

Table 5. Financial analysis summary

\begin{tabular}{lrr}
\hline & PV Inst. & Solar Thermal \\
\hline Pre-tax IRR (equity) (\%) : & $9.4 \%$ & $22.2 \%$ \\
Net Present Value (NPV) $€$ ): & 199,91 & 676,698 \\
Annual life cycle savings (yr): & 17,155 & 58,068 \\
Simple payback (yr) : & 20.8 & 5.1 \\
Benefit-Cost (B-C) Ratio : & 1.18 & 2.91 \\
GHG emission reduction $\left(\mathrm{CO}_{2}\right):$ & $2,226.5$ & 360.6 \\
\hline
\end{tabular}

The pre-tax IRR (return of the investment), which represent the true interest yield provided by the project over its life span before income tax, is for both projects positive i.e. $9.4 \%$ for the PV installation and $22.2 \%$ for the Solar-Thermal installation, making both projects acceptable. In addition, for both PV and Solar-Thermal installations NPV is positive i.e. 199,919€ and 676,698€ respectively and the simple payback period is $5.1 \mathrm{yrs}$ for the Solar-Thermal installation and 20.8yrs for the PV installation.

The RETScreen model also calculates the reduction of GHG as a result of using renewables. The resulting values of the net annual GHG emission reduction in $\mathrm{tCO}_{2}$ are also given in Table 6 .

In the following Figures 6 and 7 we can schematically see the cumulative cash flows for both PV and Solar-Thermal installations within the given project life time. 


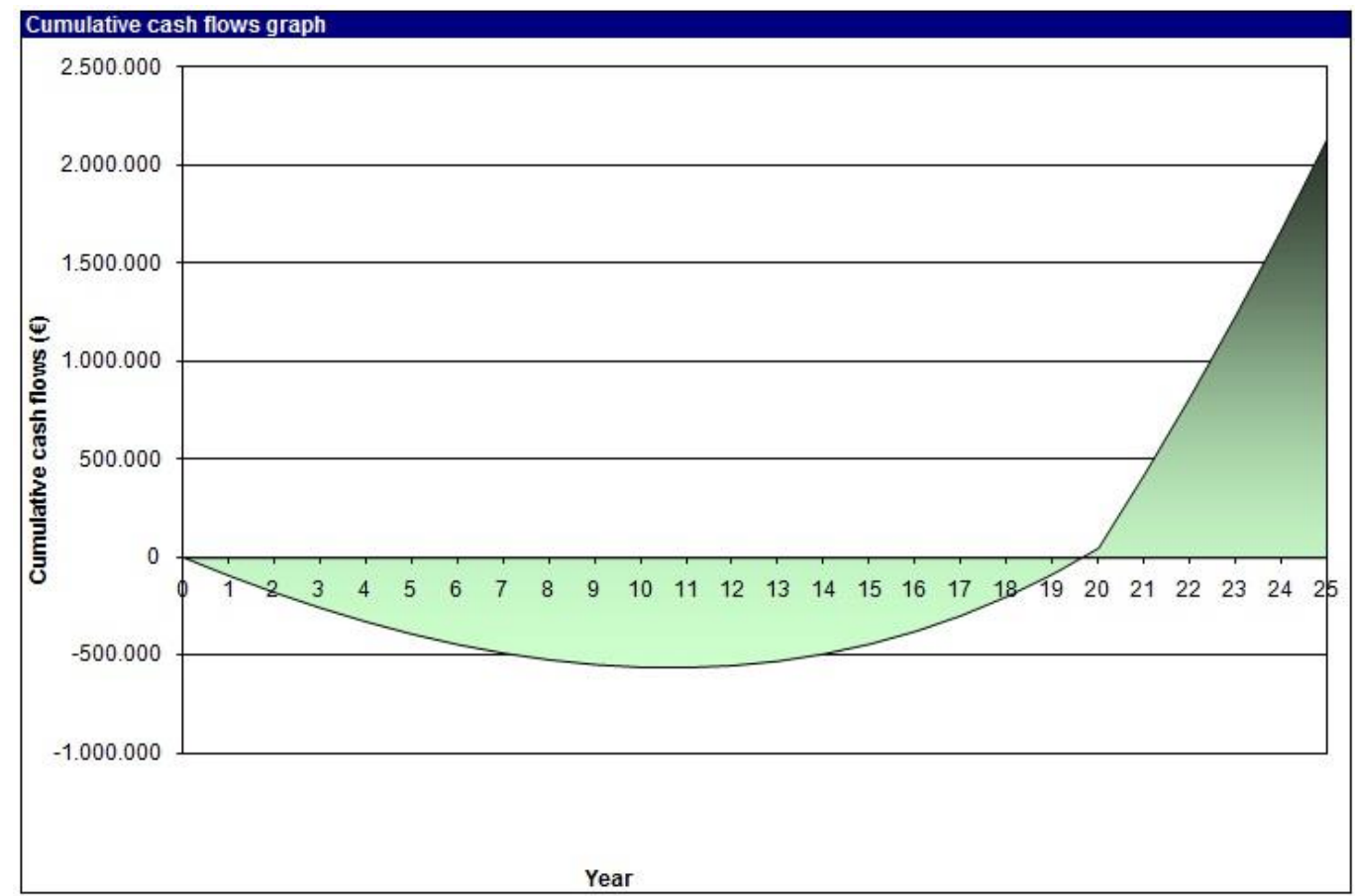

Figure 6. Cumulative cash flow of the PV installation

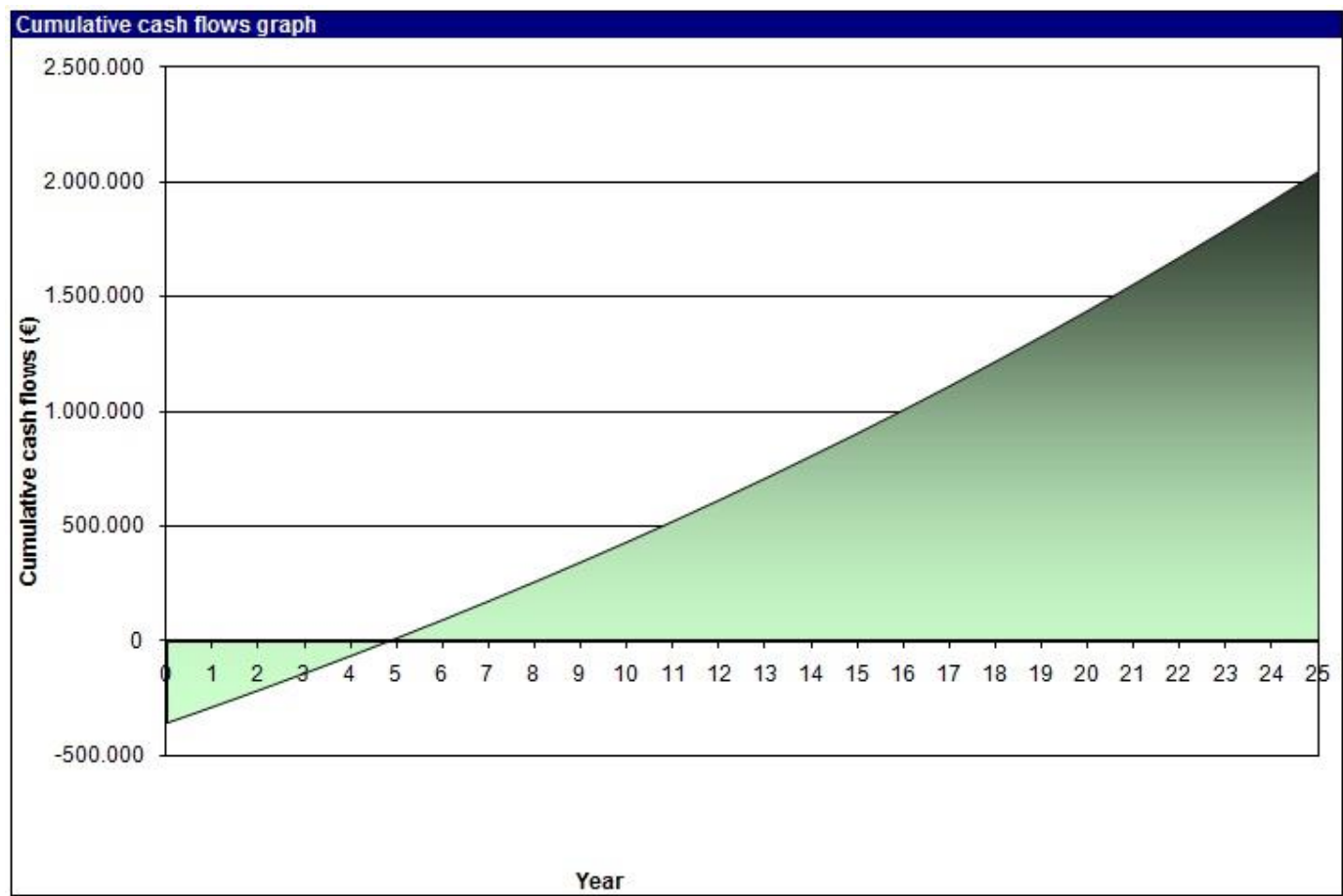

Figure 7. Cumulative cash flow of the Solar-Thermal installation

As it can be figured out, the PV installation is starting to have a limited profit from year 20 onwards, while for the Solar-Thermal installation marginal profit starts almost from year 5 .

\section{CONCLUSIONS}

In this paper we proposed a framework for renewable energy utilization and energy audit in a Mediterranean fish hatchery station. The developed framework was subsequently applied to a real case study concerning an aquaculture unit in Greece. A combined PV and Solar-Thermal panel installation is proposed, based on the energy audit results. The well-known clean energy software 
RETScreen@ International, developed by the Natural Resources of Canada, has been utilized as an assessment tool of the proposed project.

It was found that the proposed project could theoretically supply $50 \%$ and $100 \%$ of the electricity and thermal load respectively. The economic analysis concludes that the proposed project is economically feasible with payback period of 21 and 5 years for the PV and Solar-Thermal installations respectively. Nonetheless, the results of the economic analysis for the Solar-Thermal panels seem to be very optimist in contrast with the ones for the PV installation which seems to be more realistic.

Further research would focus on the development of a hybrid RES system, i.e. including in the design the exploitation of wind power. Finally it would be worth investigating whether the development of a storage system based on batteries would be economically viable, ensuring at the same time energy supply whenever needed.

\section{ACKNOWLEDGEMENTS}

The authors would like to thank the company SELODA AQUACULTURE S.A., Navarhou Nikodimou 26-30 Athens Greece, for giving access to their hatchery facility in Managouli Nafpaktos Greece, and especially Mr A. Colis and Mr St. Karagiorgos for providing the primary data for this study and offering technical advice.

\section{REFERENCES}

Ayer N.W., Tyedmers P.H., Pelletier N.L., Sonesson U., and Scholz A. (2007) Co-Product Allocation in Life Cycle Assessments of Seafood Production Systems: Review of Problems and Strategies, Int $J$ $L C A, 12,480-487$.

Ayer N., Côté R., Tyedmers P., and Martin Willison J.H. (2009) Sustainability of seafood production and consumption: an introduction to the special issue, Journal of Cleaner Production, 17, 321-324.

Ayer N.W., and Tyedmers P.H. (2009) Assessing alternative aquaculture technologies: life cycle assessment of salmonid culture systems in Canada, Journal of Cleaner Production, 17, 362-373.

Belias C.V., Bikas V.G., Dassenakis M.J., and Scoullos M.J. (2003) Environmental impacts of coastal aquaculture in eastern Mediterranean bays the case of Astakos Gulf, Greece. Environmental Science and Pollution Research, 10, 287-295.

Blancheton J.P. (2000) Developments in recirculation systems for Mediterranean fish species, Aquacultural Engineering, 22, 17-31.

Chamberlain G., and Rosenthal H. (1995) Aquaculture in the next century, opportunities for growth, challenges of sustainability, World Aquacult., 26, 21-25.

Choi Y., Rayl J., Tammineedi C., and Brownson J. (2011) PV Analyst: Coupling ArcGIS with TRNSYS to assess distributed photovoltaic potential in urban areas, Solar Energy, 85, 2924-2939.

CIHEAM (2005) Agriculture, fishery, food and sustainable rural development on the Mediterranean region, Annual report 2005, International Centre for Advanced Mediterranean Agronomic Studies

Colt J., Summerfelt S., Pfeiffer T., Fivelstad S., and Rust M. (2008) Energy and resource consumption of land-based Atlantic salmon smolt hatcheries in the Pacific Northwest (USA), Aquaculture, 280, 94108.

Dimitriou E., Katselis G., Moutopoulos D.K., Akovitiotis C., and Koutsikopoulos C. (2007) Possible influence of reared gilthead sea bream (Sparus aurata, L.) on wild stocks in the area of the Messolonghi lagoon (Ionian Sea, Greece), Aquaculture Research, 38, 398-408.

Economou A. (2010) Renewable energy resources and sustainable development in Mykonos (Greece), Renewable and Sustainable Energy Reviews, 14, 1496-1501

FAO (2006) State of world aquaculture: 2006, Food and Agriculture Organization of the United Nations, Fisheries Technical Paper, No. 500, 145pp.

Harder E., and Gibson J.M. (2011) The costs and benefits of large-scale solar photovoltaic power production in Abu Dhabi, United Arab Emirates, Renewable Energy, 36, 789-796.

Houri A. (2006) Solar water heating in Lebanon: Current status and future prospects, Renewable Energy, 31, 663-675.

Lai C.M. and Linb T.H. (2006) Technical assessment of the use of a small-scale wind power system to meet the demand for electricity in a land aquafarm in Taiwan, Renewable Energy, 31, 877-892. 
Menicou M., and Vassiliou V. (2010) Prospective energy needs in Mediterranean offshore aquaculture: Renewable and sustainable energy solutions, Renewable and Sustainable Energy Reviews, 14, 3084-3091.

Modi A., Chaudhuri A., Vijay B., and Mathur J. (2009) Performance analysis of a solar photovoltaic operated domestic refrigerator, Applied Energy, 86, 2583-2591.

Mohandes M., Balghonaim A., Kassas M., Rehman S., and Halawani T. (2000) Use of radial basis function for estimating monthly mean daily solar radiation, Solar Energy, 68, 61-168.

Moretti A., Pedini Fernandez-Criado M., and Vetillart R. (2005) Manual on hatchery production of seabass and gilthead seabream. Vol. 2. Rome, FAO, 2005, $152 \mathrm{p}$.

Moussiopoulos N., Banias G., Douros J., Michailidou A.V., and Tsegas, G., (2012) Emissions estimates and air quality impacts form the use of alternative fuels by the Titan cement factory in Thessaloniki, Global Nest Journal, 14, 218-224.

Papoutsoglou S.E. (2000) Monitoring and regulation of marine aquaculture in Greece: licensing, regulatory control and monitoring guidelines and procedures, Journal of Applied Ichthyology, 16, 167-171.

Pelletier N. and Tyedmers P. (2008) Life Cycle Considerations for Improving Sustainability Assessments in Seafood Awareness Campaigns, Environmental Management, 42, 918-931.

Pelletier N., Tyedmers P., Sonesson U., Scholz A., Ziegler F., Flysjo A., Kruse S., Cancino B. and Silverman, H. (2009) Not All Salmon Are Created Equal: Life Cycle Assessment (LCA) of Global Salmon Farming Systems, Environ. Sci. Technol., 43, 8730-8736.

Rehman S. (2005) Prospects of wind farm development in Saudi Arabia, Renewable Energy, 30, 447463.

Rehman S., Badera M., and Al-Moallem S. (2007) Cost of solar energy generated using PV panels, Renewable and Sustainable Energy Reviews, 11, 1843-1857.

Skoglund A., Leijon M., Rehn A., Lindahl M., and Waters R. (2010) On the physics of power, energy and economics of renewable electric energy sources - Part II, Renewable Energy, 35, 1735-1740.

Theodorou J. (2002) Current and Future Technological Trends of European Seabass-Seabream Culture Reviews in Fisheries Science, 10, 529-543.

\section{APPENDIX 1: DETAILED ENERGY AUDIT}

Table 6. Detailed Energy Audit

\begin{tabular}{|c|c|c|c|c|c|c|c|}
\hline \multicolumn{2}{|c|}{ A. LIVE FEED UNIT } & $\begin{array}{l}\text { LOAD } \\
\text { TYPE }\end{array}$ & $\begin{array}{l}\text { CAPACITY } \\
(\mathrm{kW})\end{array}$ & $\begin{array}{c}\text { QUANTIT } \\
Y\end{array}$ & $\begin{array}{l}\text { TOTAL } \\
\text { kW }\end{array}$ & $\begin{array}{l}\text { OPERATION } \\
h / 24 h\end{array}$ & $\begin{array}{l}\text { TOTAL } \\
\text { kWh }\end{array}$ \\
\hline 1. & Water Pumps (1.2 Hp) & Electr. & 0.88 & 4 & 3.52 & 2 & 7.04 \\
\hline 2. & Water Pumps $(1.5 \mathrm{Hp})$ & Electr. & 1.50 & 2 & 3.00 & 3 & 9.00 \\
\hline 3. & Compressor $(2.5 \mathrm{Hp})$ & Electr. & 2.00 & 1 & 2.00 & 5 & 10.00 \\
\hline 4. & Headlight & Electr. & 2.00 & 2 & 4.00 & 9 & 36.00 \\
\hline 5. & Light bulb for Algae & Electr. & 0.25 & 32 & 8.00 & 9 & 72.00 \\
\hline 6. & Light bulb for Algae & Electr. & 0.058 & 656 & 38.05 & 10 & 380.48 \\
\hline 7. & Refrigerator & Electr. & 0.75 & 2 & 1.50 & 9 & 13.50 \\
\hline 8. & Incubator & Thermal & 2.00 & 1 & 2.00 & 5 & 10.00 \\
\hline 9. & Autoclave room & Thermal & 9.00 & 2 & 18.00 & 8 & 144.00 \\
\hline 10. & A/C - "Phyto1" (25,000 BTU) & Electr. & 7.32 & 1 & 7.32 & 10 & 73.20 \\
\hline 11. & A/C - "Phyto1" (9,000 BTU) & Electr. & 2.64 & 1 & 2.64 & 10 & 26.40 \\
\hline 12. & A/C - "Phyto2" (25,000 BTU) & Electr. & 7.32 & 1 & 7.32 & 10 & 73.20 \\
\hline 13. & $\begin{array}{l}\text { A/C - "Zooplankton 1" } \\
\text { (25,000 BTU) }\end{array}$ & Electr. & 7.32 & 1 & 7.32 & 10 & 73.20 \\
\hline
\end{tabular}




\begin{tabular}{|c|c|c|c|c|c|c|c|}
\hline \multicolumn{2}{|c|}{ A. LIVE FEED UNIT } & $\begin{array}{l}\text { LOAD } \\
\text { TYPE }\end{array}$ & $\begin{array}{c}\text { CAPACITY } \\
\text { (kW) }\end{array}$ & $\begin{array}{c}\text { QUANTIT } \\
Y\end{array}$ & $\begin{array}{l}\text { TOTAL } \\
\text { kW }\end{array}$ & $\begin{array}{c}\text { OPERATION } \\
h / 24 h\end{array}$ & $\begin{array}{c}\text { TOTAL } \\
\text { kWh }\end{array}$ \\
\hline 14. & $\begin{array}{l}\text { A/C - "Zooplankton 2" } \\
(87,300 \text { BTU Cool / 91,300 } \\
\text { BTU Heat) }\end{array}$ & Electr. & 26.75 & 1 & 26.75 & 10 & 267.50 \\
\hline 15. & $\begin{array}{l}\text { A/C - Room: "Algae 1" } \\
\text { (50,800 BTU Cool / 33,600 } \\
\text { BTU Heat) }\end{array}$ & Electr. & 14.88 & 1 & 14.88 & 10 & 148.80 \\
\hline 16. & $\begin{array}{l}\text { A/C - Room: "Algae 2" } \\
\text { (87,300 BTU Cool / 91,300 } \\
\text { BTU Heat) }\end{array}$ & Electr. & 26.75 & 1 & 26.75 & 10 & 267.50 \\
\hline 17. & Central Heating & Thermal & 2.00 & 1 & 2.00 & 9 & 18.00 \\
\hline 18. & Electrical Heater - Artemia (1) & Thermal & 2.00 & 1 & 2.00 & 4 & 8.00 \\
\hline 19. & Electrical Heater - Artemia (2) & Thermal & 3.00 & 6 & 18.00 & 5 & 90.00 \\
\hline 20. & $\begin{array}{l}\text { Electrical Heater- Algae \& } \\
\text { Rotifer }\end{array}$ & Thermal & 2.00 & 7 & 14.00 & 5 & 70.00 \\
\hline 21. & Blowers (aerators) & Electr. & 7.50 & 2 & 15.00 & 11 & 165.00 \\
\hline \multicolumn{8}{|c|}{ B. HATCHERY UNIT } \\
\hline 22. & Water Pumps & Electr. & 1.80 & 2 & 3.60 & 3 & 10.80 \\
\hline 23. & Water Pumps & Electr. & 3.00 & 1 & 3.00 & 10 & 30.00 \\
\hline 24. & Water Pump (Venturri Filter) & Electr. & 4.50 & 1 & 4.50 & 8 & 36.00 \\
\hline 25. & Water Pump (submerged) & Electr. & 7.50 & 3 & 22.50 & 8 & 180.00 \\
\hline 26. & Boiler $\left(450,000 \mathrm{Kcal} \mathrm{h}^{-1}\right)$ & Thermal & 524.00 & 2 & $1,048.00$ & 3 & $3,144.00$ \\
\hline 27. & Boiler Circulator & Electr. & 4.00 & 1 & 4.00 & 10 & 40.00 \\
\hline 28. & Boiler Circulator & Electr. & 1.00 & 1 & 1.00 & 10 & 10.00 \\
\hline 29. & Blower (aerator) & Electr. & 7.50 & 2 & 15.00 & 10 & 150.00 \\
\hline 30. & Chiller & Electr. & 29.00 & 1 & 29.00 & 5 & 145.00 \\
\hline 31. & Chiller Circulator & Electr. & 4.00 & 1 & 4.00 & 8 & 32.00 \\
\hline 32. & UV Filter (Atlantium) & Electr. & 10.00 & 3 & 30.00 & 10 & 300.00 \\
\hline 33. & UV Filter (Hanovia) & Electr. & 21.00 & 1 & 21.00 & 10 & 210.00 \\
\hline 34. & Ozonizator & Electr. & 1.60 & 1 & 1.60 & 10 & 16.00 \\
\hline 35. & Refrigerator for Artemia & Electr. & 4.50 & 1 & 4.50 & 8 & 36.00 \\
\hline 36. & Freezer (3 Hp) & Electr. & 2.50 & 2 & 5.00 & 11 & 55.00 \\
\hline 37. & Freezer & Electr. & 0.16 & 3 & 0.48 & 11 & 5.28 \\
\hline 38. & Light bulbs (58 W) & Electr. & 0.058 & 44 & 2.55 & 15 & 38.25 \\
\hline 39. & PC's & Electr. & 0.15 & 2 & 0.30 & 8 & 2.40 \\
\hline 40. & Printer & Electr. & 0.05 & 2 & 0.10 & 0.5 & 0.05 \\
\hline \multicolumn{8}{|c|}{ C. BROODSTOCK UNIT } \\
\hline 41. & Light bulbs & Electr. & 0.058 & 25 & 1.45 & 6 & 8.70 \\
\hline \multicolumn{8}{|c|}{ D. WEANING UNIT } \\
\hline 42. & Water Pumps $(5.5 \mathrm{Hp})$ & Electr. & 4.50 & 9 & 40.50 & 9 & 364.50 \\
\hline
\end{tabular}




\begin{tabular}{|c|c|c|c|c|c|c|c|}
\hline \multicolumn{2}{|c|}{ A. LIVE FEED UNIT } & $\begin{array}{l}\text { LOAD } \\
\text { TYPE }\end{array}$ & $\begin{array}{l}\text { CAPACITY } \\
(\mathrm{kW})\end{array}$ & $\begin{array}{c}\text { QUANTIT } \\
Y\end{array}$ & $\begin{array}{c}\text { TOTAL } \\
\text { kW }\end{array}$ & $\begin{array}{l}\text { OPERATION } \\
\mathrm{h} / \mathbf{2 4 h}\end{array}$ & $\begin{array}{l}\text { TOTAL } \\
\text { kWh }\end{array}$ \\
\hline 43. & Water Pump $\left(100 \mathrm{~m}^{3} \mathrm{~h}^{-1}\right)$ & Electr. & 5.00 & 1 & 5.00 & 7 & 35.00 \\
\hline 44. & Water Pump $\left(200 \mathrm{~m}^{3} \mathrm{~h}^{-1}\right)$ & Electr. & 6.00 & 6 & 36.00 & 7 & 252.00 \\
\hline 45. & Water Pump $\left(200 \mathrm{~m}^{3} \mathrm{~h}^{-1}\right)$ & Electr. & 18.50 & 12 & 222.00 & 11 & 2442.00 \\
\hline 46. & UV Filter (Berson) & Electr. & 7.50 & 3 & 22.50 & 8 & 180.00 \\
\hline 47. & UV Filter $\left(1000 \mathrm{~m}^{3}\right)$ & Electr. & 21.00 & 2 & 42.00 & 11 & 462.00 \\
\hline 48. & UV Filter (backup system) & Electr. & 7.00 & 2 & 14.00 & 11 & 154.00 \\
\hline \multicolumn{8}{|c|}{ E. DRUMFILTER } \\
\hline 49. & Water Pump (5.5 Hp) & Electr. & 4.50 & 7 & 31.50 & 11 & 346.50 \\
\hline 50. & Drumfilter & Electr. & 2.05 & 1 & 2.05 & 11 & 22.55 \\
\hline \multicolumn{8}{|c|}{ F. FATTENING UNIT } \\
\hline 51. & Water Pump $\left(100 \mathrm{~m}^{3} \mathrm{~h}^{-1}\right)$ & Electr. & 5.00 & 4 & 20.00 & 7 & 140.00 \\
\hline 52. & Water Pump $\left(200 \mathrm{~m}^{3} \mathrm{~h}^{-1}\right)$ & Electr. & 6.00 & 4 & 24.00 & 7 & 168.00 \\
\hline \multicolumn{8}{|c|}{ G. CENTRAL PUMPING STATION } \\
\hline 53. & Water Pumps $\left(600 \mathrm{~m}^{3} \mathrm{~h}^{-1}\right)$ & Electr. & 45.00 & 2 & 90.00 & 11 & 990.00 \\
\hline 54. & Water Pumps & Electr. & 37.00 & 2 & 74.00 & 11 & 814.00 \\
\hline 55. & Water Pumps (30 Hp) & Electr. & 25.00 & 1 & 25.00 & 8 & 200.00 \\
\hline \multicolumn{8}{|c|}{ H. ADMINISTRATION BUILDING } \\
\hline 56. & PC's & Electr. & 0.15 & 6 & 0.90 & 8 & 7.2 \\
\hline 57. & Printer & Electr. & 0.05 & 4 & 0.20 & 1 & 0.20 \\
\hline 58. & Fax, scanner etc. & Electr. & 0.017 & 1 & 0.017 & 1 & 0.017 \\
\hline 59. & Coffee machine & Electr. & 2.00 & 1 & 2.00 & 1.5 & 3.00 \\
\hline 60. & Room A/C (12.000 BTU) & Electr. & 3.52 & 4 & 14.08 & 6 & 84.48 \\
\hline \multicolumn{2}{|r|}{ TOTAL } & & 958.64 & & 2091.38 & & 13019.41 \\
\hline
\end{tabular}

